\title{
THE INVESTIGATION OF GROUNDWATER HYDROCHEMISTRY OF KHEZRI PLAIN, SOUTH KHORASAN PROVINCE, IRAN
}

\author{
Hosniyeh zarepourfard ${ }^{1 *}$, Ahmad Aryafar ${ }^{2}$, Hasan $_{\text {zia }^{3}}$ \\ ${ }^{1}$ MSc Students, Department of Mining, Faculty of Engineering, University of Birjand, Iran \\ ${ }^{2}$ Department of Mining, Faculty of Engineering, University of Birjand, Iran \\ ${ }^{3}$ Department of Mining, Faculty of Engineering, University of Birjand, Iran \\ *Corresponding author email: h.zarepour@birjand.ac.ir
}

This is an open access article distributed under the Creative Commons Attribution License, which permits unrestricted use, distribution, and reproduction in any medium, provided the original work is properly cited

ARTICLE DETAILS
Article history:
Received 12 October 2017 Accepted
12 November 2017 Available online
20 Disember 2017
Keywords:
Groundwater quality, Hydrochemistry,
Schoeller diagrams, Wilcox diagrams,
Khezri basin

\section{ABSTRACT}

The investigation of groundwater quality is one of the most important subjects in the field of groundwater resource. The main purpose of this research is the study of groundwater samples witch have been collected from 12 and 9 pumping wells throughout $1385-1394$ years. The samples have been analyzed for major cations ( $\mathrm{Na}, \mathrm{K}, \mathrm{Mg}$ and $\mathrm{Ca}$ ), major anions ( $\mathrm{Cl}, \mathrm{SO} 4, \mathrm{HCO} 3$ andCO3) and physical parameters such as TDS, TH, Ec and pH. In following, the hydrogeochemical graphs such as Piper diagrams used for water classification. The analysis of results showed the increasing of TDS, TH and EC upper the limit. According to Schoeller and Wilcox diagrams, the water is not suitable for drinking purposes, agricultural and industrial uses. Such results are more helpful to manage the groundwater resource.

\section{INTRODUCTION}

Today, with increasing population growth as well as the expansion of industries, two major dilemmas are the lack of water and pollution of human resources [1, 2]. Also, in recent years, increasing water requirements and limitation of surface water resources and overexploitation of groundwater aquifers have caused irreparable damage to natural resources of the country in [3]. The main and only reliable source of water supply in arid and semi-arid and desert areas, especially in the event of droughts, is groundwater resources. In addition to the sharp decline in water level in aquifers, agricultural, industrial, quantitative and qualitative activities, management and exploitation and protection of groundwater should be considered as a basis for planning of the country [4].

Underground water solves various materials through different layers of the earth. These materials are due to the erosion of rocks, the existence of evaporative and sedimentary structures and their dissolution, such as gypsum, salt, iron, etc. As a result, their quality will change according to the length of the path and the presence of dissolution materials along the path in different points $[5,6]$.

This issue reveals the necessity of recognizing the effects of different parts of the earth on the chemical quality of water and identifying the rate of this effectiveness over time. In general, their geological formations and their chemical weathering have a major role in controlling natural water composition [7]. up to now various studies have been carried out on groundwater hydrochemistry. A studied the properties of groundwater hydrochemistry in agricultural land [8]. For this purpose, 55 samples from agricultural wells are divided into three groups. This research shows that the quality of groundwater and the geochemistry of the area depends on its geology. Some researchers conducted a review of Fetzara Lake Water Hydrochemistry to assess groundwater quality for drinking or farming [9]. They found that groundwater chemistry is more dependent on the interaction of water and bedrock, but is often also affected by other factors, such as steam and ion exchange.

\section{THE STUDY AREA}

Khezri study area sub-basin of salt Khaf Petregan playa Iran's South Khorasan Province lengths between $58^{\circ} 35^{\prime}$ to $5917^{\prime}$ East and $33^{\circ} 41^{\prime}$ to $34^{\circ} 06^{\prime}$ North is located. The North and North-East to the area Gysvr and gonabad, from East and South East to the range Esfeden and Qaen and South West and West to the range Musaviyeh well and sarayan have been limited. Khezri surrounding mountains often constitute Jurassic and Cretaceous rocks. In the northern half of Shemshak are more widespread and includes the layers of sandstone and slate, which cover more areas north of West Plains. Tab of this formation are observed in regions of the North East. Cretaceous rocks in this part of the Cretaceous limestone thin to medium low. Other units of the Eocene northern highlands and is mostly red conglomerates. Castle in the highlands of the southern half of them girls, shale, sandstone and limestone, sandstone and shale Shemshak Formation of Jurassic and Cretaceous limestone different units thick stone wall Flisch, shale and sandstone, etc., etc. have [10]. In Figure 3, the khezri geographical position has been shown.

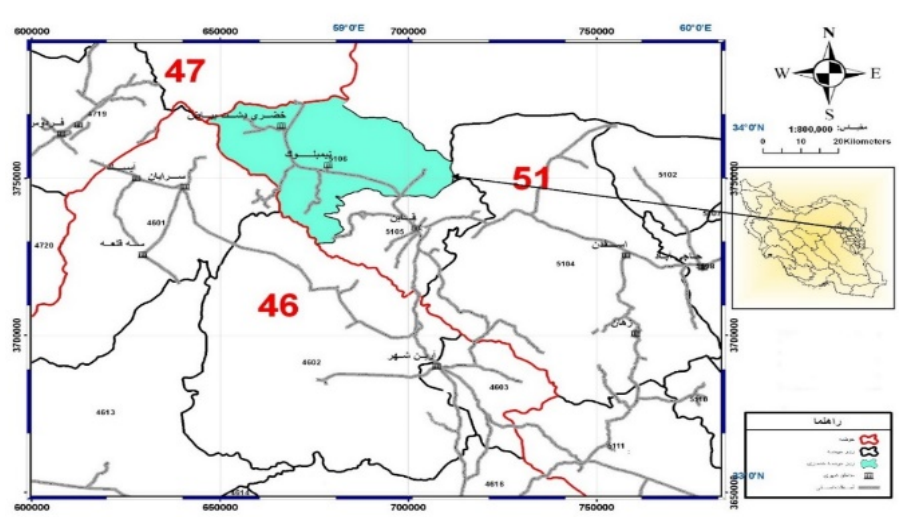

Figure 1: The study area [10]

\section{RESULTS AND DISCUSSION}

Check the quality of groundwater, in addition to the importance of determining the type of water quality for various uses, also helps us to understand some of the hydrological issues of the groundwater table. The chemical quality of underground water varies depending on the type and composition of the perimeter of the plain (nutritional sources) and alluvium [11]. In order to evaluate the groundwater quality in Khezri plain, a well-selected well was selected in Khezri plain in the years 1385 and 1394. After sampling EC, TDS, $\mathrm{pH}, \mathrm{Ca} 2+, \mathrm{Mg} 2+, \mathrm{Na}+, \mathrm{K}+$, Hco3-, Co3-, Cl-, So42- and ph were determined. The descriptive statistics of the hydrochemical parameters are presented in the following tables. 
Table 1: Descriptive statistics of samples in 1385 (in ppm)

\begin{tabular}{|c|c|c|c|c|c|c|c|c|c|c|c|}
\hline $\mathrm{SO}_{4}$ & $\mathrm{Cl}$ & $\mathrm{CO}_{3}$ & $\begin{array}{r}\mathrm{HC} \\
\mathrm{O}_{3}\end{array}$ & $\mathrm{~K}$ & $\mathrm{Na}$ & $\mathrm{Mg}$ & $\mathrm{Ca}$ & PH & TDS & EC & $\begin{array}{r}\text { paramete } \\
\mathrm{r}\end{array}$ \\
\hline $12 / 98$ & $\begin{array}{r}1 / 72 \\
7\end{array}$ & $0 / 43$ & $5 / 16$ & $0 / 1$ & $\begin{array}{r}2 / 02 \\
5\end{array}$ & $5 / 22$ & $5 / 89$ & $8 / 66$ & $\begin{array}{r}406 / 1 \\
8\end{array}$ & $\begin{array}{r}411 / 2 \\
4\end{array}$ & $\begin{array}{r}\text { arithmeti } \\
\text { c mean }\end{array}$ \\
\hline $17 / 3$ & $\begin{array}{r}2 / 23 \\
1\end{array}$ & $0 / 34$ & $2 / 12$ & $\begin{array}{r}/ 04 \\
0\end{array}$ & $\begin{array}{r}2 / 17 \\
0\end{array}$ & $1 / 7$ & $5 / 95$ & $0 / 35$ & 5046 & $\begin{array}{r}355 / 5 \\
4\end{array}$ & $\begin{array}{l}\text { Standard } \\
\text { deviation }\end{array}$ \\
\hline $\begin{array}{r}13 / 28 \\
3\end{array}$ & $\begin{array}{r}11 / 8 \\
9\end{array}$ & $\begin{array}{r}7 / 07 \\
9\end{array}$ & $\begin{array}{r}4 / 09 \\
1\end{array}$ & 40 & $\begin{array}{r}8 / 62 \\
0\end{array}$ & $\begin{array}{r}3 / 57 \\
2\end{array}$ & $\begin{array}{r}10 / 02 \\
1\end{array}$ & $4 / 04$ & $\begin{array}{r}12 / 04 \\
4\end{array}$ & $86 / 4$ & \begin{tabular}{rr}
\multicolumn{2}{c}{ Coefficie } \\
nt of \\
variation \\
$(\%)$ \\
\end{tabular} \\
\hline $61 / 34$ & 61 & $0 / 8$ & $8 / 3$ & $0 / 2$ & $\begin{array}{r}5 / 73 \\
6\end{array}$ & $8 / 7$ & $18 / 1$ & 8/95 & $\begin{array}{r}1842 \\
3 \\
\end{array}$ & $\begin{array}{r}1030 \\
0\end{array}$ & $\begin{array}{r}\text { Maximu } \\
\mathrm{m}\end{array}$ \\
\hline $0 / 3$ & $3 / 2$ & 0 & $1 / 4$ & $\begin{array}{r}105 \\
0 \\
\end{array}$ & $3 / 56$ & $2 / 3$ & $1 / 6$ & $7 / 76$ & $697 / 6$ & 1090 & $\begin{array}{r}\text { Minimu } \\
\mathrm{m} \\
\end{array}$ \\
\hline $0 / 5$ & ردندا & $0 / 8$ & مدندار & $\begin{array}{r}/ 07 \\
0 \\
\end{array}$ & ردندا & $6 / 9$ & $1 / 6$ & ردندا & مدارد & ندارد & Fashion \\
\hline $6 / 88$ & 7/95 & $0 / 5$ & $5 / 5$ & $\begin{array}{r}09 \\
0 \\
\end{array}$ & $\begin{array}{r}1 / 04 \\
8 \\
\end{array}$ & $4 / 9$ & $3 / 1$ & $8 / 77$ & 1936 & 2525 & Middle \\
\hline $61 / 04$ & $57 / 8$ & $0 / 8$ & $6 / 9$ & $\begin{array}{r}/ 15 \\
0\end{array}$ & $\begin{array}{r}5 / 17 \\
3\end{array}$ & $6 / 4$ & $16 / 5$ & $1 / 19$ & $\begin{array}{r}1772 \\
5\end{array}$ & 9210 & $\begin{array}{r}\text { variation } \\
\text { range }\end{array}$ \\
\hline $2 / 24$ & $1 / 53$ & $0 / 18$ & $0 / 43$ & $1 / 5$ & $0 / 78$ & $0 / 46$ & $1 / 42$ & $1 / 89$ & $2 / 39$ & $1 / 12$ & Skidding \\
\hline $\begin{array}{r}29 / 34 \\
9 \\
\end{array}$ & $\begin{array}{r}45 / 6 \\
0 \\
\end{array}$ & $0 / 12$ & $4 / 5$ & 0 & $\begin{array}{r}40 / 8 \\
6 \\
\end{array}$ & $2 / 9$ & $35 / 41$ & $0 / 12$ & $\begin{array}{l}3 \mathrm{E} 07 \\
+\quad \\
\end{array}$ & $\begin{array}{l}1 \mathrm{E} 07 \\
+\quad \\
\end{array}$ & Variance \\
\hline
\end{tabular}

Table 2: Descriptive statistics of samples in 1394 (in ppm)

\begin{tabular}{|c|c|c|c|c|c|c|c|c|c|c|c|}
\hline $\mathrm{SO}_{4}$ & $\mathrm{Cl}$ & $\begin{array}{r}\mathrm{CO} \\
3 \\
\end{array}$ & $\begin{array}{r}\mathrm{HCO} \\
3\end{array}$ & K & $\mathrm{Na}$ & $\mathrm{Mg}$ & $\mathrm{Ca}$ & $\mathrm{PH}$ & TDS & EC & $\begin{array}{r}\text { paramete } \\
\mathrm{r}\end{array}$ \\
\hline $7 / 28$ & 8/96 & 0 & $8 / 61$ & $0 / 03$ & $\begin{array}{r}1 / 36 \\
2\end{array}$ & 9/69 & $2 / 27$ & $\begin{array}{r}112 \\
7\end{array}$ & $\begin{array}{r}161 / 9 \\
0\end{array}$ & $\begin{array}{l}253 / 8 \\
3\end{array}$ & $\begin{array}{r}\text { arithmeti } \\
\text { c mean }\end{array}$ \\
\hline $3 / 51$ & $3 / 16$ & 0 & $2 / 29$ & $0 / 01$ & $4 / 31$ & $4 / 49$ & $1 / 27$ & $\begin{array}{r}131 \\
0\end{array}$ & $\begin{array}{r}52 / 02 \\
3\end{array}$ & $\begin{array}{r}82 / 45 \\
4 \\
\end{array}$ & $\begin{array}{r}\text { Standard } \\
\text { deviation }\end{array}$ \\
\hline $\begin{array}{r}4 / 21 \\
8\end{array}$ & $\begin{array}{r}3 / 27 \\
5\end{array}$ & 0 & $26 / 6$ & $\begin{array}{r}3 / 33 \\
3\end{array}$ & $\begin{array}{r}3 / 87 \\
4\end{array}$ & $\begin{array}{r}4 / 34 \\
6\end{array}$ & $\begin{array}{r}5 / 95 \\
5\end{array}$ & $\begin{array}{r}135 \\
4\end{array}$ & $32 / 47$ & $32 / 54$ & $\begin{array}{r}\text { Coefficie } \\
\text { nt of } \\
\text { variation } \\
\text { (\%) }\end{array}$ \\
\hline $12 / 3$ & $13 / 6$ & 0 & $12 / 4$ & $0 / 04$ & $18 / 6$ & $16 / 2$ & $4 / 8$ & $\begin{array}{r}182 \\
7 \\
\end{array}$ & $\begin{array}{r}236 / 4 \\
7 \\
\end{array}$ & 3720 & $\begin{array}{r}\text { Maximu } \\
\mathrm{m}\end{array}$ \\
\hline $2 / 2$ & 4 & 0 & $5 / 5$ & $0 / 02$ & $5 / 5$ & $3 / 9$ & $1 / 1$ & $\begin{array}{r}182 \\
6 \\
\end{array}$ & $758 / 2$ & 1187 & $\begin{array}{r}\text { Minimu } \\
\mathrm{m}\end{array}$ \\
\hline $6 / 7$ & $9 / 6$ & 0 & 8 & $0 / 02$ & 12 & $10 / 6$ & $1 / 6$ & $\begin{array}{r}104 \\
7 \\
\end{array}$ & 1662 & 2610 & Fashion \\
\hline $10 / 1$ & $9 / 6$ & 0 & $6 / 9$ & $0 / 02$ & $13 / 1$ & $12 / 3$ & $3 / 7$ & 1 & $\begin{array}{r}160 / 2 \\
9\end{array}$ & 2533 & Middle \\
\hline $0 / 04$ & $0 / 26$ & 0 & $0 / 3$ & $0 / 82$ & $0 / 11$ & 0 & $1 / 21$ & $\begin{array}{r}71 \\
1 \\
\end{array}$ & $-0 / 04$ & $-0 / 04$ & $\begin{array}{r}\text { variation } \\
\text { range }\end{array}$ \\
\hline $\begin{array}{r}1 / 33 \\
2 \\
\end{array}$ & 9/98 & 0 & $5 / 23$ & 0 & $\begin{array}{r}1 / 56 \\
8 \\
\end{array}$ & $\begin{array}{r}2 / 13 \\
0 \\
\end{array}$ & $1 / 62$ & $0 / 1$ & $\begin{array}{r}27354 \\
6 \\
\end{array}$ & 67971 & Skidding \\
\hline
\end{tabular}

Accurately in the amounts presented in the above tables, we can say that the average electrical conductivity (EC) in water samples taken from 1394 has decreased compared to 1385 but its value is still high. These high levels of electrical conductivity indicate that water is inappropriate for agricultural use, and especially for drinking. Also, the total dry solids (TDS) amount of water samples evaporated from water samples decreased from 1385 to 1394 . The amount of TDS authorized by the World Health Organization (WHO) is $\mathrm{mg} / \mathrm{l} 1000$, which exceeds the permitted amount in each of the two selected years, which indicates a deterioration in the groundwater level of the area during this period.

Figures $\mathbf{2}$ and $\mathbf{3}$ show a map of the distribution of water conductivity values for the studied period.

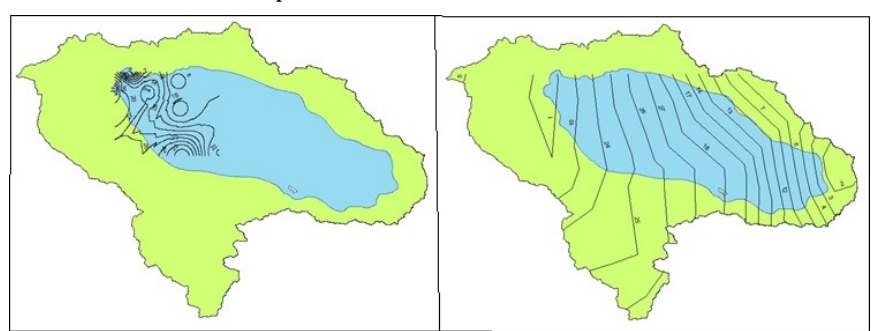

Figure 2: Electrical Conductivity Map (EC) of 1385 Fig. 3: Electrical Conductivity Map (EC) of 1394

\subsection{Type and facies of water in Khezri plain}

To study the type and facies of groundwater in Khedri plain, piper diagram has been used. Piper's diagram is one of the most important charts for displaying and comparing water qualitative analyzes provided by Piper. This diagram simply reveals differences and similarities between groundwater samples. Similar quality water tends to be grouped together [12]. According to the Piper diagrams presented in 1385 and 1394, the status and general type of water samples are often found in the area of sodium-chlorine-sulfate and saline water.

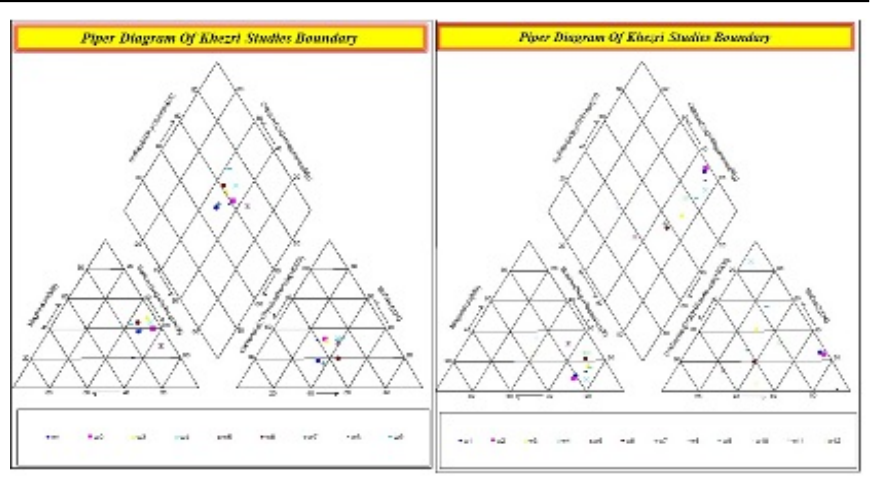

Figure 3: Piper diagram for samples in 1385 Figure 3: Piper diagram for samples of 1394

\subsection{Groundwater quality assessment of Khezri Plain for various uses}

The Schooller diagram is used to compare groundwater quality. This diagram shows the exact value of each ion, and also shows the differences in concentrations between groundwater samples; on the other hand, the Schooller diagram is used in the division of drinking water. By comparing the two above diagrams, it is easy to see the qualitative changes in water. Reducing the amount of $\mathrm{mg}$ and increasing the amount of ca causes the water to approach the hardness. Certain increases in cl also indicate a decrease in water quality for drinking.

Figures $\mathbf{4}$ and $\mathbf{5}$ show the Schooller diagrams for groundwater of the studied area.

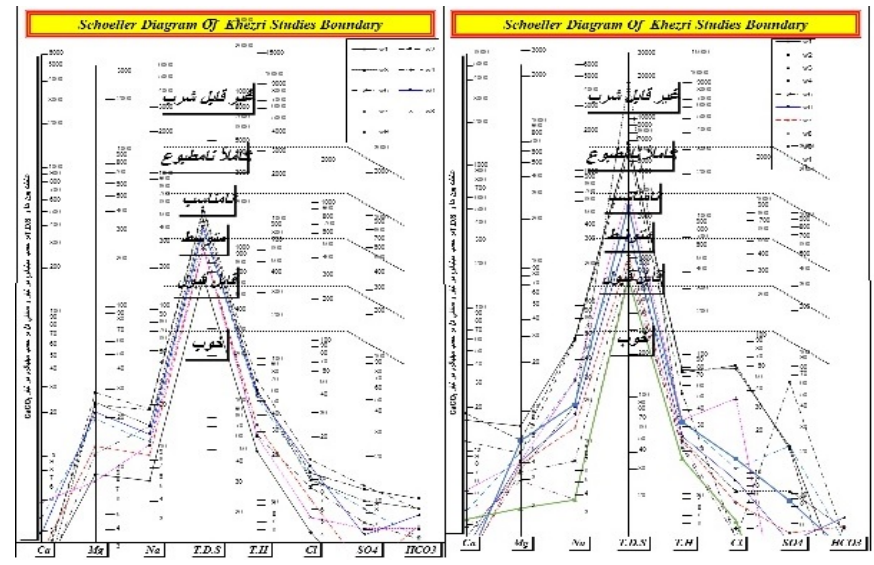

Figure 4: Schooller diagrams for samples in 1385 Figure: 5: Schooller diagrams for samples of 1394

To show different agricultural groups, the Wilcox diagrams are used in which two important factors of ec and SAR are used for water classification. The above diagrams show the water status of the area for agricultural consumption. According to the charts, all samples in both years are in terms of values (EC) in the range of more than 750 micrometers per $\mathrm{cm}$ and less than 5,000 micromos per $\mathrm{cm}$. In Tables 3 and 4 , the classification of water for agricultural purposes is presented in the years 85 and 94 .

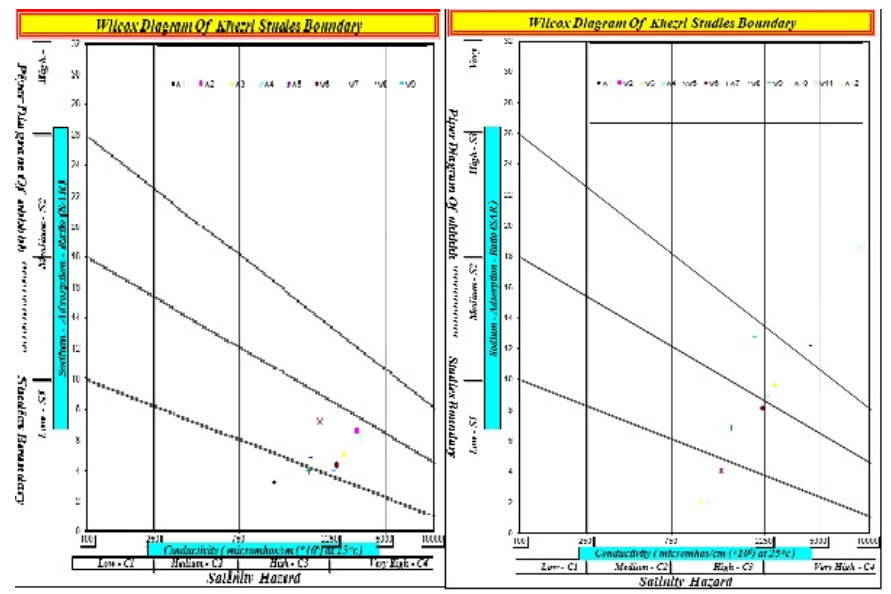

Figure 6: Weil-Cox diagram for 1385 Figure 7: Weil-Cox diagram for 
Table 3: Water quality classification for agricultural use in 1385

\begin{tabular}{|l|r|r|r|r|r|}
\hline Water $\begin{array}{r}\text { quality for } \\
\text { agriculture }\end{array}$ & $\begin{array}{r}\text { Water } \\
\text { class }\end{array}$ & EC & SAR & Abbreviation & Sampling site \\
\hline $\begin{array}{l}\text { Very passionate - for } \\
\text { inappropriate agricultural }\end{array}$ & C4-S4 & 10100 & 15.99 & w1 & $\begin{array}{r}\text { Mohammad Abad Alam } \\
\text { Ayoubi }\end{array}$ \\
\hline $\begin{array}{l}\text { Very passionate - for } \\
\text { inappropriate agricultural }\end{array}$ & C4-S4 & 10300 & 16.05 & w2 & $\begin{array}{r}\text { Mohammad Abad Alam } \\
\text { Ghasem Yaghoubzadeh }\end{array}$ \\
\hline $\begin{array}{r}\text { Very passionate - for } \\
\text { inappropriate agricultural }\end{array}$ & C4-S3 & 2880 & 9.66 & w3 & $\begin{array}{r}\text { Islamabad Water Well } \\
\text { No. 15 }\end{array}$ \\
\hline $\begin{array}{r}\text { Very passionate - for } \\
\text { inappropriate agricultural }\end{array}$ & C4-S4 & 8950 & 18.58 & w4 & Islam Abad Ghasemi \\
\hline $\begin{array}{r}\text { Salted - Can be used for } \\
\text { agriculture }\end{array}$ & C3-S1 & 1420 & 4.08 & w5 & $\begin{array}{r}\text { Islamabad Water Well } \\
\text { No. 1 }\end{array}$ \\
\hline $\begin{array}{l}\text { Very passionate - for } \\
\text { inappropriate agricultural }\end{array}$ & C4-S2 & 2450 & 8.13 & w6 & $\begin{array}{r}\text { Khezri } \\
\text { wells } \\
\text { companies }\end{array}$ \\
\hline $\begin{array}{r}\text { Salted - Can used for } \\
\text { agriculture }\end{array}$ & C3-S2 & 1620 & 6.86 & w7 & $\begin{array}{r}\text { Khezri } \\
\text { wells } \\
\text { companies }\end{array}$ \\
\hline $\begin{array}{r}\text { Very passionate - for } \\
\text { inappropriate agricultural }\end{array}$ & C4-S4 & 4550 & 12.13 & w8 & Ishraqi KheZri \\
\hline $\begin{array}{r}\text { Salted - Can be used for } \\
\text { agriculture }\end{array}$ & C3-S3 & 2200 & 12.71 & w9 & Khezri Well 6 \\
\hline $\begin{array}{r}\text { Salted - Can be used for } \\
\text { agriculture }\end{array}$ & C3-S1 & 1210 & 2 & w10 & Plain Beyaz Owners \\
\hline $\begin{array}{l}\text { Very passionate - for } \\
\text { inappropriate agricultural }\end{array}$ & C4-S3 & 2600 & 8.86 & w11 & Feyaz Abad Malik \\
\hline $\begin{array}{l}\text { Salted - Can be used for } \\
\text { agriculture }\end{array}$ & C3-S1 & 1090 & 2.13 & w12 & Khezri Jafari \\
\hline
\end{tabular}

Table 4: Water quality classification for agricultural use in 1395

\begin{tabular}{|c|c|c|c|c|c|}
\hline Water quality for agriculture & $\begin{array}{l}\text { Water } \\
\text { class }\end{array}$ & EC & SAR & Abbreviation & Sampling site \\
\hline $\begin{array}{c}\text { Salted - Can be } \begin{array}{c}\text { used for } \\
\text { agriculture }\end{array} \\
\end{array}$ & C3-S1 & 1187 & $3 / 2$ & w1 & Beyaz Plain \\
\hline $\begin{array}{lcr}\text { Very } & \begin{array}{c}\text { passionate } \\
\text { inappropriate agricultural }\end{array} \\
\end{array}$ & $\mathrm{C} 4-\mathrm{S} 2$ & 3550 & $6 / 67$ & w2 & Feyzabad \\
\hline $\begin{array}{ccr}\text { Very } & \text { passionate } & \text { for } \\
\text { inappropriate agricultural }\end{array}$ & C4-S2 & 3010 & $5 / 11$ & w3 & Bassun \\
\hline $\begin{array}{ccr}\text { Very } & \begin{array}{c}\text { passionate } \\
\text { inappropriate agricultural }\end{array} \\
\end{array}$ & 4-S2 & 3720 & $6 / 27$ & w4 & $\begin{array}{r}\text { Well number } \\
19 \\
\end{array}$ \\
\hline $\begin{array}{l}\text { Salted - Can be } \begin{array}{c}\text { used for } \\
\text { agriculture }\end{array} \\
\end{array}$ & C3-S2 & 2190 & $7 / 17$ & w5 & Islamabad 6 \\
\hline $\begin{array}{ccr}\text { Very } & \begin{array}{c}\text { passionate } \\
\text { inappropriate agricultural }\end{array} \\
\end{array}$ & HS2 & 2730 & $4 / 41$ & w6 & Feyzabad \\
\hline $\begin{array}{r}\text { Salted - Can be } \begin{array}{c}\text { used for } \\
\text { agriculture }\end{array} \\
\end{array}$ & 3-S1 & 1891 & $4 / 01$ & w7 & Khezri \\
\hline $\begin{array}{l}\text { Salted - Can be used for } \\
\text { agriculture }\end{array}$ & -S2 & 1916 & $4 / 84$ & w8 & Well No. 9 \\
\hline Very $\begin{array}{c}\text { passionate }- \text { for } \\
\text { inappropriate agricultural }\end{array}$ & C4-S2 & 2610 & $3 / 93$ & w9 & Well No. 6 \\
\hline
\end{tabular}

Underground water quality classification for industrial uses is often based on hardness, corrosion and shelling.

Table 4 showes the classification of water for industrial use in terms of the corrosivity and toughness of the entire aquifer.

Table 5: Water Classification for Industrial Use 1385

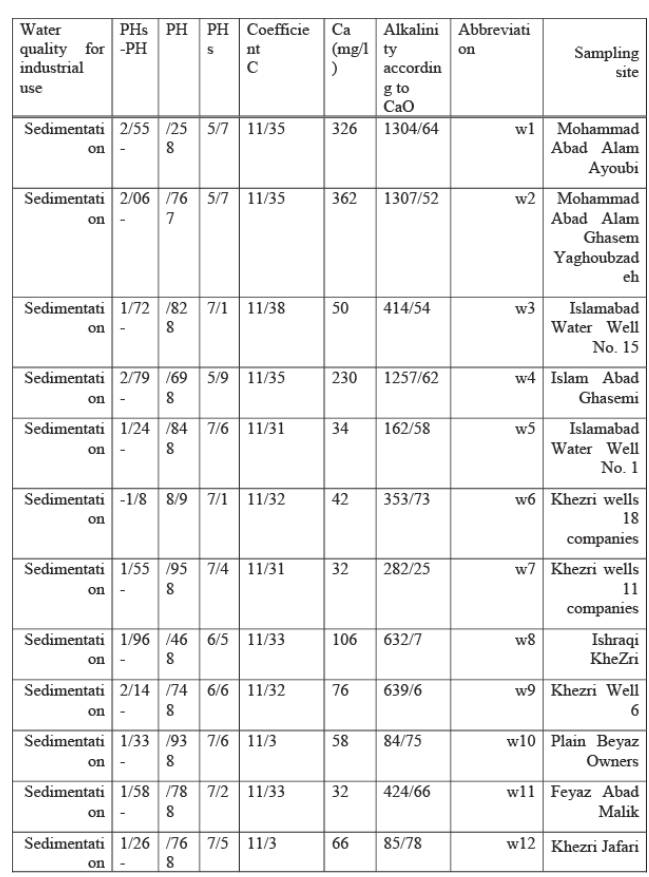

Table 6: Water Classification for Industrial Use 1394

\begin{tabular}{|r|l|l|l|l|l|l|r|r|}
\hline $\begin{array}{l}\text { Water quality } \\
\text { for industrial } \\
\text { use }\end{array}$ & $\begin{array}{l}\mathrm{pHs} \\
\mathrm{pH}\end{array}$ & $\mathrm{pH}$ & $\mathrm{pHs}$ & $\begin{array}{r}\text { Coefficient } \\
\mathrm{C}\end{array}$ & $\begin{array}{l}\mathrm{Ca} \\
(\mathrm{mg} / 1)\end{array}$ & $\begin{array}{r}\text { Alkalinity } \\
\text { according } \\
\text { to }\end{array}$ & Abbreviation & $\begin{array}{l}\text { Sampling } \\
\text { site }\end{array}$ \\
\hline Corrosive & $0 / 7$ & 7 & $7 / 7$ & $11 / 3$ & 30 & $127 / 28$ & $\mathrm{w1}$ & $\begin{array}{r}\text { Beyaz } \\
\text { Plain }\end{array}$ \\
\hline Sedimentation & $-0 / 21$ & $7 / 41$ & $7 / 2$ & $11 / 33$ & 32 & $420 / 16$ & $\mathrm{w} 2$ & Feyzabad \\
\hline Sedimentation & $-0 / 32$ & $7 / 82$ & $7 / 5$ & $11 / 32$ & 22 & $323 / 17$ & w3 & Bassun \\
\hline Corrosive & $0 / 48$ & $6 / 82$ & $7 / 3$ & $11 / 33$ & 28 & $429 / 36$ & w4 & $\begin{array}{r}\text { Well } \\
\text { number } \\
19\end{array}$ \\
\hline Corrosive & $0 / 46$ & $6 / 94$ & $7 / 4$ & $11 / 32$ & 26 & $318 / 18$ & w5 & $\begin{array}{r}\text { Islamabad } \\
6\end{array}$ \\
\hline Corrosive & $0 / 21$ & $6 / 89$ & $7 / 1$ & $11 / 32$ & 58 & $277 / 17$ & w6 & Feyzabad \\
\hline Corrosive & $0 / 3$ & $7 / 1$ & $7 / 4$ & $11 / 31$ & 42 & $196 / 28$ & w7 & Khezri \\
\hline Sedimentation & $-0 / 04$ & $7 / 04$ & 7 & $11 / 31$ & 96 & $233 / 08$ & w8 & $\begin{array}{r}\text { Well No. } \\
9\end{array}$ \\
\hline Corrosive & $0 / 04$ & $7 / 06$ & $7 / 1$ & $11 / 32$ & 74 & $242 / 28$ & w9 & $\begin{array}{r}\text { Well No. } \\
6\end{array}$ \\
\hline
\end{tabular}

\section{CONCLUSION}

The study of hydrodynamic data of Khezri Plain during the years 85 and 94 shows that by observing the total changes and the EC map, be said that water quality has decreased, The main reason for this is the decline in weather conditions. And an increase in the amount of exploitation (decrease in storage volume). According to the Piper diagram, the water type is located within the sodium-chlorine-sulfate zone.In the Schooller diagram, water is also a difficult one that is not suitable for drinking.

The Wilcox chart also shows the tendency for water to precipitate and salinity Which is also not very suitable for agriculture and is not used for industrial purposes, which can be deduced according to Tables 4 and 5 .

In general, the quality of water quality changes in Khazri Plain was undesirable. And coping with it requires extensive and comprehensive attention in order to reduce and control the amount of water harvesting, geological studies prior to drilling and implementation of watershed management and artificial nutrition plans to compensate for groundwater resources.

\section{REFERENCE}

[1] Zhao, Z., Wu, J., Yuan, G., Chen, J., Xu, X., Yan, C., Bai, Y. 2016. Hydro chemical investigation of shallow groundwater in northwest margin of Lop Nur, northwest China. Environmental Earth Sciences, 75 (3), 214.

[2] Wan, Y. Y., Liu, F. T., and Lin, G. Y. 2012. Study on the Hydraulic Relationship between Molin River and Groundwater. in Advanced Materials Research, 490, 652-656: Trans Tech Publ.

[3] Ravikumar, P., Somashekar, R. K., and Angami, M. 2011. Hydrochemistry and evaluation of groundwater suitability for irrigation and drinking purposes in the Markandeya River basin, Belgaum District, Karnataka State, India. Environmental monitoring and assessment, 173 (1),459-487.

[4] Armengol, S., Manzano, M., Bea, S. A., and Martínez, S. 2017. Identifying and quantifying geochemical and mixing processes in the Matanza-Riachuelo Aquifer System, Argentina. The Science of the total environment, 599, 1417.

[5] Wu, X., Pan, M., Zhu, X., Cao, J., and Zhang, M. 2017. Effect of extreme precipitation events on the hydrochemistry index and stable isotope compositions of drip water in a subtropical cave, Guangxi, SW China. Carbonates and Evaporites, 1-9.

[6] Vrebos, D., Beauchard, O., and Meire, P. 2017. The impact of land use and spatial mediated processes on the water quality in a river system. Science of The Total Environment, 601, 365-373.

[7] Fianko, J. R., Nartey, V. K., and Donkor, A. 2010. The hydrochemistry of groundwater in rural communities within the Tema District, Ghana. Environmental monitoring and assessment, 168 (1), 441-449.

[8] Chae, G.T., Kim, K., Seong, T.Y., HoKim, K., Kim, S.O., Choi, B.Y., Kim, H.S., Rhee, C.W. 2004. Hydro geochemistry of alluvial groundwaters in an agricultural area: an implication for groundwater contamination susceptibility. Chemosphere, 55 (3), 369-378.

[9] Abdelkader, R., Larbi, D., Rihab, H., Fethi, B., Chemseddine, F., and Azzedine, H. 2012. Geochemical characterization of groundwater from shallow aquifer surrounding Fetzara Lake NE Algeria. Arabian Journal of Geosciences, 5 (1), 1-13. 
[10] Report of Prohibition of Khazari plain, 1391.

[11] Bicalho, C. C., Batiot-Guilhe, C., Seidel, J. L., Van Exter, S., and Jourde, H. 2012. Hydrodynamical changes and their consequences on groundwater hydrochemistry induced by three decades of intense exploitation in a Mediterranean Karst system. Environmental Earth Sciences, 65 (8), 2311-2319.

[12] Piper, Arthur M. 1944. A graphic procedure in the geochemical interpretation of water-analyses. Eos, Transactions American Geophysical Union, 25 (6), 914-928. 